\title{
Review of the efficacy and safety of remifentanil for the prevention and treatment of pain during and after procedures and surgery
}

This article was published in the following Dove Press journal:

Local and Regional Anesthesia

14 July 2010

Number of times this article has been viewed

\author{
Erica L Sivak \\ Peter J Davis \\ Department of Anesthesiology, \\ Children's Hospital of Pittsburgh \\ of UPMC, University of Pittsburgh \\ School of Medicine, Pittsburgh, \\ Pennsylvania, USA
}

\begin{abstract}
Remifentanil is an ultrashort-acting synthetic opioid. It is metabolized by nonspecific tissue and plasma esterases. Remifentanil's metabolism is responsible for its unique pharmacokinetic profile and flat, context-sensitive half-time. Since its introduction into clinical practice, remifentanil has been used for a variety of anesthetic and analgesic applications; however, concerns regarding a potential for rapid induction of tolerance and/or induced hyperalgesia, coupled with an ultrarapid offset of effect, make the drug less than optimal for use in the pharmacologic management of pain.
\end{abstract}

Keywords: regional anesthesia, intravenous anesthesia, tolerance, hyperalgesia, rapid offset

\section{Discussion \\ Pharmacologic principles}

Remifentanil is a synthetic opioid receptor agonist. It is a 4-anilidopiperidine with ester side chain, by which it is metabolized by nonspecific blood and tissue esterases to the renally excreted, inactive metabolite, carboxylic acid (GR90291). ${ }^{1}$ In healthy adult volunteers, remifentanil has a short elimination half-life of 9.5 ( \pm 4 minutes) minutes ${ }^{1}$ and its clearance is three to four times greater than liver blood flow. ${ }^{2}$ Like other opioids, remifentanil's volume of distribution has an inverse relationship with age. However, unlike other opioids that depend on end organ elimination for drug clearance and have the lowest clearance values in the neonatal period, remifentanil clearance is highest in the neonatal period. Because of the age-related changes in volume of distribution and the inverse relationship of age with clearance, there are no age-related changes in remifentanil's half-life. ${ }^{3}$ Perhaps the most interesting characteristic of remifentanil is its context-sensitive half-time, which remains constant or flat regardless of the duration of infusion. ${ }^{4,5}$ The context-sensitive half-time in healthy adults was determined to be 3.2 minutes and pharmacodynamic offset was 5.4 minutes. $^{5}$

Organ failure changes the metabolism of many drugs; however, end stage hepatic or renal failure does not affect remifentanil clearance. In a study performed in 12 adult patients undergoing liver transplantation, Navapurkur demonstrated that clearance during the anhepatic stage of liver transplant was similar to clearance in healthy adults. ${ }^{6}$ In patients with end organ renal disease, Hoke and others noted that remifentanil's clearance was not affected by renal failure, but there was a marked reduction in elimination of GR90291, the metabolite of remifentanil, which does not appear to have clinical significance. ${ }^{7}$ Although tissue and plasma esterases metabolize remifentanil, pseudocholinesterase deficiency does not alter the drug's metabolism either in vivo or in vitro. In vitro studies reported by Davis and colleagues, using blood
Correspondence: Peter J Davis Department of Anesthesiology Children's Hospital of Pittsburgh 440I Penn Avenue

Pittsburgh, Pennsylvania I5224-I529

$\mathrm{Tel}+\mathrm{I} 4126925260$

Fax + I 4126928658

Email davispj@anes.upmc.edu 
and plasma from butyrylcholinesterase deficient patients, showed a similar half-life to that of volunteers with normal butyrylcholinesterase levels. ${ }^{8}$ In addition, a published case report by Manullang and others noted a normal duration of remifentanil effect in a patient with known pseudocholinesterase deficiency. ${ }^{9}$

Remifentanil can be used to reduce the minimum alveolar concentration (MAC) of volatile anesthetic agents. In healthy adults having elective surgery under general anesthesia, Lang reported that the MAC of isoflurane was reduced by onethird with $1 \mathrm{ng} / \mathrm{mL}$ blood concentration of remifentanil. ${ }^{10}$ At plasma concentrations of $4-8 \mathrm{ng} / \mathrm{mL}$ of remifentanil, isoflurane MAC could be further reduced by $65 \%-70 \%$. There was, however, a ceiling effect of remifentanil on MAC reduction. The maximum reduction of isoflurane's MAC by remifentanil was $92 \%$. Thus, remifentanil is not suitable as a sole anesthetic agent and is used in conjunction with other anesthetic and/or hypnotic drugs.

\section{Remifentanil as an adjunct anesthetic agent}

Given the unique pharmacokinetic properties of remifentanil, it has been used extensively for a wide variety of surgical procedures and in a wide age range of patients, from neonates to geriatric patients. ${ }^{10}$ Table 1 demonstrates that infusions of remifentanil are rapidly titratable and predictable with respect to its onset and offset of effect. Thus remifentanil, as part of an outpatient surgical procedure, may provide fast emergence from anesthesia and early patient discharge from the facility. Studies have been done to compare desflurane and remifentanil anesthetics to desflurane alone, and found that recovery time was faster with remifentanil, with no difference in postoperative nausea and vomiting (PONV), or need for analgesic medications. ${ }^{11}$ In a study of women undergoing outpatient gynecologic surgery, Beers and colleagues compared fentanyl with remifentanil anesthetic. Although no difference was observed in recovery times, postanesthesia care unit (PACU) pain scores, or fentanyl consumption postoperatively, the authors did note that patients in the remifentanil group had greater incidences of both PONV and rescue antiemetic treatment. ${ }^{12}$ In a study of women undergoing breast surgery, Hong and others compared sevoflurane and nitrous oxide to infusions of propofol and remifentanil. ${ }^{13}$ Patients receiving the propofol-remifentanil combination had faster induction and emergence times, but no significant difference was noted in facility discharge times. Emergence from a remifentanil-propofol anesthetic and return of cognitive function was demonstrated to be faster than that of nitrous oxide combined with either sevoflurane or desflurane. ${ }^{14}$ The difference was only measurable in the first 90 minutes after the anesthetics after which the cognitive function appeared to be the same in all groups.

Remifentanil use has been reported in pediatric patients. In a study of children undergoing tonsillectomy and adenoidectomy, Davis and others compared the following anesthetic regimens: 1) halothane and fentanyl bolus; 2) halothane and remifentanil infusion; 3) sevoflurane and fentanyl bolus; and 4) sevoflurane and remifentanil infusion. ${ }^{15}$ Children in the groups receiving remifentanil had faster emergence and extubation times, but higher pain scores in the recovery room. There was no difference among the groups in time to discharge from the facility. In a study of children aged 2-12 years undergoing strabismus surgery, Eltschig and colleagues compared fentanyl and remifentanil anesthetics. ${ }^{16}$ Postoperatively, the fentanyl group experienced a higher frequency of postoperative nausea and vomiting, but significantly lower

Table I Studies of remifentanil use during general anesthesia

\begin{tabular}{|c|c|c|c|c|c|c|c|c|}
\hline Study & Surgery & Control group & Study group & $\mathbf{N}$ & $\begin{array}{l}\text { Recovery } \\
\text { time }\end{array}$ & PONV & $\begin{array}{l}\text { Discharge } \\
\text { time }\end{array}$ & $\begin{array}{l}\text { Postoperative } \\
\text { pain }\end{array}$ \\
\hline Song et al' & Gyn & $\begin{array}{l}\text { Des titration and } \\
\mathrm{N}_{2} \mathrm{O}\end{array}$ & $\begin{array}{l}\text { Remi titration, with } \\
\text { Des } 2 \%, \mathrm{~N}_{2} \mathrm{O}\end{array}$ & 46 & $\begin{array}{l}>\text { control } \\
\text { group }\end{array}$ & $\begin{array}{l}\text { No } \\
\text { difference }\end{array}$ & NR & No difference \\
\hline Beers et $\mathrm{al}^{12}$ & Gyn & Fentanyl & Remi & 34 & $\begin{array}{l}\text { No } \\
\text { difference }\end{array}$ & $\begin{array}{l}>\text { study } \\
\text { group }\end{array}$ & NR & No difference \\
\hline Hong et $\mathrm{al}^{13}$ & Breast & $\begin{array}{l}\text { Sevo/ } \mathrm{N}_{2} \mathrm{O} / \\
\text { Fentanyl }\end{array}$ & Remi/propofol & 42 & $\begin{array}{l}>\text { control } \\
\text { group }\end{array}$ & $\begin{array}{l}>\text { control } \\
\text { group }\end{array}$ & Similar & $>$ study group \\
\hline Larsen et $\mathrm{al}^{14}$ & Orthopedic & $\begin{array}{l}\text { Sevo } / \mathrm{N}_{2} \mathrm{O} \text { or } \\
\text { Des } / \mathrm{N}_{2} \mathrm{O}\end{array}$ & Remi/propofol & 60 & $\begin{array}{l}>\text { control } \\
\text { groups }\end{array}$ & $\begin{array}{l}\text { No } \\
\text { difference }\end{array}$ & NR & No difference \\
\hline Davis et $\mathrm{al}^{15}$ & $\begin{array}{l}\text { Pediatric } \\
\text { tonsil/adenoid }\end{array}$ & $\begin{array}{l}\text { Sevo/fentanyl or } \\
\text { Hal/fentanyl }\end{array}$ & $\begin{array}{l}\text { Sevo/remi or } \\
\mathrm{Hal} / \text { remi }\end{array}$ & 206 & $\begin{array}{l}>\text { control } \\
\text { groups }\end{array}$ & $\begin{array}{l}\text { No } \\
\text { difference }\end{array}$ & $\begin{array}{l}\text { No } \\
\text { difference }\end{array}$ & $>$ study group \\
\hline Eltzschig et $\mathrm{al}^{16}$ & $\begin{array}{l}\text { Pediatric } \\
\text { strabismus }\end{array}$ & Fentanyl & Remi & 81 & NR & $\begin{array}{l}>\text { control } \\
\text { group }\end{array}$ & NR & $\begin{array}{l}>\text { study group } \\
\text { early }\end{array}$ \\
\hline
\end{tabular}


pain scores in the early postoperative period. Another study of pediatric strabismus surgery compared remifentanil, alfentanil, isoflurane, and propofol, and found that the group receiving remifentanil reported higher pain scores in the recovery room. ${ }^{17}$ Remifentanil, combined with propofol, has also been studied to provide procedural sedation for children undergoing lumbar puncture. ${ }^{18}$

Remifentanil has been demonstrated to be effective for sedation combined with regional anesthesia. Table 2 shows the results of the study done by Lauwers and colleagues, which studied 160 patients undergoing either spinal or brachial plexus nerve block in trial, and comparing different doses of remifentanil infusion with placebo. ${ }^{19}$ Remifentanil infusion was effective at providing sedation, reducing the necessary dose of midazolam, and promoting a quick return to alertness (10-12 min). However, remifentanil also increased nausea, pruritus, sweating, and respiratory side effects. In a smaller study by Lauwers of 28 patients, remifentanil and propofol were compared after spinal or axillary anesthesia. ${ }^{20}$ While similar levels of sedation were achieved with both regimens, the group receiving propofol had a $20 \%$ decrease in mean arterial blood pressure and heart rate. The remifentanil group demonstrated greater hemodynamic stability but with a higher incidence of nausea and respiratory depression. Two different groups have also reported studies comparing propofol with remifentanil infusions for sedation during surgery performed under regional block. ${ }^{21,22}$ During both studies, remifentanil was more effective at preventing pain, but was associated with an increased incidence of nausea and respiratory depression. Krenn and colleagues studied patients sedated with remifentanil or propofol who were scheduled to undergo carotid endarterectomy under cervical plexus block. ${ }^{23}$ Although both remifentanil and propofol provided adequate sedation, patients receiving remifentanil experienced a greater incidence of respiratory depression and increase in arterial carbon dioxide tensions $\left(\mathrm{PaCO}_{2}\right)$. Savoia and colleagues studied 328 vascular surgery patients anesthetized with a regional block, including deep and superficial cervical block, lumbar epidural or plexus block, combined with various hypnotic agents, propofol or midazolam with either sufentanil or remifentanil. ${ }^{24}$ Their group reported successful sedation using either propofol $<3 \mathrm{mg} / \mathrm{kg} / \mathrm{h}$ or midazolam $0.5-3 \mathrm{mg}$ with sufentanil $5-10 \mu \mathrm{g} / \mathrm{hr}$ or remifentanil $0.05 \mu \mathrm{g} / \mathrm{kg} / \mathrm{min}$. Further combinations and techniques of sedation, including remifentanil, combined with regional anesthesia were reviewed by Höhener and colleagues. ${ }^{25}$ This paper reported use of remifentanil infusions from $0.03-0.5 \mu \mathrm{g} / \mathrm{kg} / \mathrm{min}$ or bolus $0.5-1 \mu \mathrm{g} / \mathrm{kg}$ combined with plexus, spinal, or retrobulbar block. Given the ultrashort action of remifentanil, bolus administration was used to facilitate block placement during ophthalmologic surgery, and then propofol infusion for sedation.

Use of remifentanil combined with propofol has been studied in patients undergoing procedural sedation. Mandel

Table 2 Studies of remifentanil use with regional anesthesia

\begin{tabular}{|c|c|c|c|c|c|c|c|}
\hline Study & Surgery & $\begin{array}{l}\text { Type of } \\
\text { regional }\end{array}$ & $\begin{array}{l}\text { Control } \\
\text { group }\end{array}$ & $\begin{array}{l}\text { Study } \\
\text { group }\end{array}$ & $\mathbf{N}$ & $\begin{array}{l}\text { Measured } \\
\text { outcome }\end{array}$ & $\begin{array}{l}\text { Adverse } \\
\text { effects }\end{array}$ \\
\hline Lauwers et al ${ }^{19}$ & Orthopedic & $\begin{array}{l}\text { Spinal or } \\
\text { brachial plexus }\end{array}$ & $\begin{array}{l}\text { Placebo with } \\
\text { midazolam }\end{array}$ & $\begin{array}{l}\text { Remifentanil } \\
\text { infusion with } \\
\text { midazolam }\end{array}$ & 160 & $\begin{array}{l}>\text { sedation and } \\
<\text { midazolam } \\
\text { required in } \\
\text { study group }\end{array}$ & $\begin{array}{l}\text { Respiratory } \\
\text { depression, } \\
\text { PONV, } \\
\text { pruritis }\end{array}$ \\
\hline Lauwers et $\mathrm{al}^{20}$ & Orthopedic & Spinal or axillary & $\begin{array}{l}\text { Propofol } \\
\text { infusion }\end{array}$ & $\begin{array}{l}\text { Remifentanil } \\
\text { infusion }\end{array}$ & 28 & $\begin{array}{l}\text { Sedation and } \\
\text { comfort equal }\end{array}$ & $\begin{array}{l}\text { >respiratory } \\
\text { depression } \\
\text { and nausea in } \\
\text { study group }\end{array}$ \\
\hline Mingus et $\mathrm{al}^{21}$ & $\begin{array}{l}\text { Orthopedic or } \\
\text { urologic }\end{array}$ & $\begin{array}{l}\text { Spinal, axillary } \\
\text { or ankle }\end{array}$ & $\begin{array}{l}\text { Propofol } \\
\text { infusion }\end{array}$ & $\begin{array}{l}\text { Remifentanil } \\
\text { infusion }\end{array}$ & 107 & $\begin{array}{l}\text { >pain relief in } \\
\text { study group }\end{array}$ & $\begin{array}{l}\text { >respiratory } \\
\text { depression } \\
\text { and nausea in } \\
\text { study group }\end{array}$ \\
\hline Krenn et $\mathrm{a}^{23}$ & $\begin{array}{l}\text { Carotid } \\
\text { endarterectomy }\end{array}$ & Cervical plexus & $\begin{array}{l}\text { Propofol } \\
\text { infusion }\end{array}$ & Remifentanil & 60 & $\begin{array}{l}\text { No difference } \\
\text { in sedation or } \\
\text { hemodynamic } \\
\text { variables }\end{array}$ & $\begin{array}{l}\text { >respiratory } \\
\text { depression } \\
\text { and } \mathrm{PaCO}_{2} \text { in } \\
\text { study group }\end{array}$ \\
\hline Servin et $\mathrm{a}^{22}$ & $\begin{array}{l}\text { Orthopedic, urologic, } \\
\text { gynecologic, vascular }\end{array}$ & $\begin{array}{l}\text { Neuraxial or } \\
\text { peripheral block }\end{array}$ & Propofol & Remifentanil & 125 & $\begin{array}{l}>\text { pain relief in } \\
\text { study group }\end{array}$ & $\begin{array}{l}\text { >respiratory } \\
\text { depression } \\
\text { and nausea in } \\
\text { study group }\end{array}$ \\
\hline
\end{tabular}


and colleagues compared propofol and remifentanil with midazolam and fentanyl in adults undergoing colonoscopy. ${ }^{26}$ Both groups were treated with patient-controlled infusions of study medications. The infusions each had an initial bolus dose, demand doses, and lockout times. The patients in the remifentanil/propofol group were sedated faster (3.4 \pm 1.3 minutes vs $7.6 \pm 3.6$ minutes), able to ambulate earlier (9.2 \pm 4 minutes vs $36.4 \pm 5.3$ minutes), and spent significantly less time in the recovery room ( $4.9 \pm 4.3$ minutes vs $32 \pm 25$ minutes). Procedure time was not significantly different between groups; however, two patients in the remifentanil/propofol group required intervention for hypoxia $\left(\mathrm{SaO}_{2}<85 \%\right)$. In another study evaluating the effectiveness of remifentanil in adult patients undergoing colonoscopy in spontaneously ventilating patients, Moerman's group examined propofol and remifentanil infusions where remifentanil was administered manually, either as a bolus followed by a continuous infusion, or as a target-controlled infusion to a preset concentration of $1 \mathrm{ng} / \mathrm{ml} .{ }^{27} \mathrm{In}$ addition, a third group (control group) received a propofol infusion alone. In all three groups, propofol was administered using targetcontrolled infusions with the initial target concentration set to $4 \mu \mathrm{g} / \mathrm{mL}$. The propofol target levels were then adjusted based on clinical indications (patient movement, ventilation, and responsiveness to verbal commands). Although patients in the placebo group moved, coughed, and hiccupped more than either of the remifentanil groups (and so interfering with the colonoscopy), the remifentanil groups had more respiratory side effects requiring intervention. The targetcontrolled remifentanil infusion group received less total remifentanil and experienced fewer respiratory complications than the group that received remifentanil manually. Recovery appeared to be fastest in the target-controlled remifentanil group; however recovery in this study was defined only as the times at which the patient opened their eyes, followed commands, and correctly stated their date of birth, not actual discharge time.

\section{Remifentanil as an analgesic agent}

Remifentanil can be used for postoperative pain control if it is administered by a constant infusion or by patient-controlled analgesia (PCA). Table 3 shows the results of 56 women Choi studied who underwent abdominal hysterectomy and compared postoperative remifentanil vs fentanyl infusions with respect to postoperative pain control. There was no clear difference in pain scores, the use of other analgesics, or side effects in either group. However, three episodes (10.7\%) of serious respiratory depression requiring intervention occurred in the remifentanil group. ${ }^{28}$ The researchers reported these cases of respiratory depression in a letter to the editor of Anesthesia and Analgesia. ${ }^{29}$ All three cases were thought to have been a result of small boluses of remifentanil being administered inadvertently, either during replacement of an infusion bag or with the administration of another drug in the same IV tubing. These cases highlight the need for careful monitoring of patients receiving narcotic infusions, and perhaps makes a case for not utilizing remifentanil infusions on busy nursing floors where monitoring is more difficult. Kucukemre and colleagues reported that after major abdominal surgery, patients could be managed with either remifentanil or morphine PCA with good outcomes. ${ }^{30}$ In this randomized study of 60 patients, there were no statistical differences with respect to hemodynamic, respiratory, sedation or visual analogue scores between the remifentanil and morphine groups; however, there were more bolus doses demanded and delivered in the remifentanil group.

Remifentanil PCA treatment has been reported by Gurbet and colleagues for use in patients after cardiac surgery. ${ }^{31}$ This randomized, double-blinded study compared remifentanil, morphine, and fentanyl PCA utilizing continuous and

Table 3 Studies of remifentanil as an analgesic

\begin{tabular}{|c|c|c|c|c|c|c|c|}
\hline Study & Surgery & $\begin{array}{l}\text { Control } \\
\text { group }\end{array}$ & Study group & $\mathbf{N}$ & Pain scores & PONV & Adverse events \\
\hline Choi et $\mathrm{al}^{28}$ & $\begin{array}{l}\text { Abdominal } \\
\text { hysterectomy }\end{array}$ & $\begin{array}{l}\text { Fentanyl } \\
\text { infusion }\end{array}$ & $\begin{array}{l}\text { Remifentanil } \\
\text { infusion }\end{array}$ & 56 & No difference & No difference & $\begin{array}{l}\text { Respiratory depression in } \\
\text { study group }\end{array}$ \\
\hline $\begin{array}{l}\text { Kucukemre } \\
\text { et } \mathrm{al}^{30}\end{array}$ & $\begin{array}{l}\text { Abdominal } \\
\text { surgery }\end{array}$ & $\begin{array}{l}\text { Morphine } \\
\text { PCA }\end{array}$ & $\begin{array}{l}\text { Remifentanil } \\
\text { PCA }\end{array}$ & 60 & No difference & No difference & $\begin{array}{l}\text { Apnea after loading dose of } \\
\text { remifentanil in one patient }\end{array}$ \\
\hline $\begin{array}{l}\text { Gurbet } \\
\text { et } \mathrm{al}^{31}\end{array}$ & $\begin{array}{l}\text { Cardiac } \\
\text { Surgery }\end{array}$ & $\begin{array}{l}\text { Morphine or } \\
\text { Fentanyl PCA }\end{array}$ & $\begin{array}{l}\text { Remifentanil } \\
\text { PCA }\end{array}$ & 75 & No difference & $>$ morphine group & Pruritis in fentanyl group \\
\hline $\begin{array}{l}\text { Baltali } \\
\text { et } \mathrm{al}^{32}\end{array}$ & $\begin{array}{l}\text { Cardiac } \\
\text { surgery }\end{array}$ & $\begin{array}{l}\text { Morphine } \\
\text { PCA }\end{array}$ & $\begin{array}{l}\text { Remifentanil } \\
\text { PCA }\end{array}$ & 60 & $\begin{array}{l}<\text { pain with cough and } \\
\text { movement in study group }\end{array}$ & No difference & No difference \\
\hline $\begin{array}{l}\text { Volmanen } \\
\text { et } \mathrm{al}^{35}\end{array}$ & $\begin{array}{l}\text { Labor } \\
\text { analgesia }\end{array}$ & $\begin{array}{l}\text { Epidural } \\
\text { bupivicaine }\end{array}$ & $\begin{array}{l}\text { Remifentanil } \\
\text { PCA }\end{array}$ & 52 & $<$ pain in control group & $>$ study group & $\begin{array}{l}\text { Maternal desaturation, } \\
\text { sedation in study group }\end{array}$ \\
\hline
\end{tabular}


bolus doses in 75 off-pump, coronary artery bypass surgery patients, beginning immediately after completion of the surgery. Pain scores, sedation, and extubation times were all similar. Demand and delivered doses were higher in the remifentanil group, but nausea and vomiting and pruritus were all lower in the remifentanil group. Baltai's group also examined coronary artery bypass surgery patients and compared remifentanil to morphine. ${ }^{32}$ This group found that pain scores with both cough and movement were lower in the group receiving remifentanil. At the conclusion of PCA usage, the need for supplemental pain medications was similar for both groups.

The use of remifentanil has been reported in obstetrical patients where IV narcotics are used cautiously for fear of causing fetal depression. ${ }^{33}$ Volmanen has reported on the use of remifentanil PCA in parturients who did not receive neuraxial pain control. Although remifentanil rapidly crosses the placenta, these authors noted low umbilical vein to artery ratio (0.29) and suggested that remifentanil undergoes rapid metabolism and redistribution in the fetus. The dose range for effective labor PCA was examined in a study of 20 women with results ranging from $0.2 \mu \mathrm{g} / \mathrm{kg}$ to $0.8 \mu \mathrm{g} / \mathrm{kg}$ with lockout times of one minute. ${ }^{34}$ All women received remifentanil PCA with bolus doses alone during the first stage of labor for 60 minutes, and were followed for an additional 20 minutes after the infusion was discontinued. Three women were removed from the study because they entered the second stage of labor prior to completion of 60 minutes of remifentanil infusion. Pain scores decreased by an average of 4 points on a $0-10$ VAS (visual analog scale). Side effects, including maternal oxygen desaturation, sedation, and decreased beat-to-beat variability in fetal heart rate were observed during this study. All but one infant, including the infants of the three women prematurely discontinued from the study, were delivered with Apgar scores $>8$; the exception was born 6 hours after last remifentanil dose with Apgars of 6 and 7 at 1 and 5 minutes respectively. This baby's mother was treated for suspected chorioamnionitis.

In a follow-up study of another group of parturient patients studied during early labor (defined as cervical dilation of 4-7 cm), Volmanen compared PCA remifentanil with bolus epidural bupivicaine and fentanyl. ${ }^{35}$ The authors noted that pain scores reported on a 0-10 scale were higher (7.3) in the remifentanil group compared with the epidural group (5.2), but average pain relief scores, which were reported on a $0-4$ scale with $0=$ no relief to $4=$ complete relief, were not different between the two groups (median scores of 2.8 for the epidural group and 2.5 for the remifentanil group). Sedation and hypoxia were more common in the remifentanil group. In a feasibility study of 21 parturients allowed to administer PCA remifentanil $(0.25-0.5 \mu \mathrm{g} / \mathrm{kg})$ beginning at $3 \mathrm{~cm}$ cervical dilation and continuing up until the time of delivery, Blair noted no significant reductions in fetal heart rate defined as $<110$; median 1 and 5 minute Apgar scores were 8 and 9 respectively; and mean infant cord $\mathrm{pH}$ was 7.34 in the women who continued remifentanil until delivery. Thirteen continued to use remifentanil until the time of delivery, four decided to change to a regional technique during the first stage of labor, one changed to a regional technique during second stage (which required forceps delivery), and three required a regional technique for Caesarean section. ${ }^{36}$

Based on the current evidence, remifentanil PCA is a reasonable solution for parturients who desire pain medication during labor but are not candidates for, or not accepting of, neuraxial anesthesia. There is a paucity of studies comparing neuraxial analgesia to remifentanil analgesia to recommend replacement of neuraxial analgesia at this time.

\section{Opioid hyperalgesia}

Opioid induced hyperalgesia, or the increased perception of pain following administration of opioids, is a topic that has been studied since the 1970s. Even short (30-90 minute) remifentanil infusions have been reported to result in hyperalgesia. ${ }^{37}$ The exact mechanism of opioid induced hyperalgesia is unknown, but there are many different theories as to where within the pain pathways this may occur. The proposed mechanisms include: sensitization of peripheral nerve endings, enhanced descending nociceptive signal transmission, enhanced production, release and decreased reuptake of nociceptive neurotransmitters, and sensitization of secondorder neurons to nociceptive neurotransmitters. ${ }^{37}$

Varying doses of remifentanil infusions have been studied to determine if an association exists between remifentanil dose and the development of hyperalgesia. In 2007 Schmidt's group studied 42 adult patients undergoing eye surgery with isoflurane and remifentanil anesthesia. ${ }^{38}$ Patients were randomized to receive either high $(0.4 \mu \mathrm{g} / \mathrm{kg} / \mathrm{min})$ or low $(0.1 \mu \mathrm{g} / \mathrm{kg} / \mathrm{min})$ dose remifentanil. Hyperalgesia was assessed by enhanced sensitivity to pressure stimulation postoperatively. Patients were assessed postoperatively for surgical site pain, and if VAS $>3$ they were treated with analgesics and eliminated from the rest of the study. This resulted in five patients from each group (high and low remifentanil doses) being eliminated. In the remaining 32 patients, the use of high dose, but not low dose, remifentanil was associated with development of hyperalgesia to painful 
pressure. No patient in this study developed a positive response to cold stimuli as tested in the patient's hands and forearms. The reason for the difference in response to different types of stimuli is unknown, but the authors of this paper suggested that perhaps this could be explained by different neurons carrying signals for different types of pain. Mechanical pain (pressure in this model) is thought to be carried by $A ß$ fibers, with $A \partial$ fibers being responsible for cold detection. Perhaps opioid induced hyperalgesia affects different neuronal fibers differently. Rodent models have also been used to examine the influence of dose and duration of remifentanil infusion on hyperalgesia. In these animal models, the extent and duration of thermal and mechanical hyperalgesia was related to the administered dose of remifentanil; however, the duration of the infusion did not influence the development of hyperalgesia. ${ }^{39}$

Another area of interest regarding opioid induced hyperalgesia has focused on the N-methyl-D-aspartate (NMDA) receptor. This receptor is found throughout the brain and spinal cord and utilizes glutamate to transmit pain signals. In a study by Zhao and others involving rat dorsal horn neurons cultured and treated with remifentanil, these investigators noted that remifentanil induced an acute increase in the NMDA response, as evidenced by an increase in peak current amplitudes ${ }^{40}$ This may suggest that enhancement of NMDA responses by remifentanil is responsible for opioid induced hyperalgesia or tolerance. In another set of experiments reported in the same paper, the investigators noted that the observed enhancement of NMDA receptors (increase in peak current amplitudes) could be attenuated by either $\mu$ or $\partial$ antagonists such as naloxone and naltrindole. Selective $\partial$-opioid agonists, enkephalin and deltorphin II, were able to attenuate the response seen at NMDA receptors. Thus, administering a $\partial$-opioid antagonist along with remifentanil may diminish opioid induced hyperalgesia while preserving opioid function at $\mu$ pain receptors.

Ketamine, a NMDA receptor antagonist, has been studied as a possible treatment for opioid induced hyperalgesia. In adult patients undergoing abdominal surgery, $\mathrm{Fu}$ and others studied the effect of low dose, subanalgesic ketamine administered prior to incision and then continued as an infusion. In this study, the investigators noted that ketamine administration decreased total morphine consumption. ${ }^{41}$ However, no intraoperative narcotics were administered, so while ketamine may have an opioid sparing effect, the study design precluded comments regarding hyperalgesia. Guillou and others also studied the effects of low dose ketamine in adult patients undergoing abdominal surgery. In this study, sufentanil was administered intraoperatively for maintenance of anesthesia and ketamine was administered postoperatively. ${ }^{42}$ The study also demonstrated that the administration of ketamine reduced total morphine consumption in the postoperative period. However, since no ketamine was administered during the procedure, the question of whether ketamine has an effect on narcotic hyperalgesia remains unanswered. Neither of these studies examined the role of ketamine with respect to remifentanil administration, but do show a narcotic sparing effect of NMDA receptor antagonists.

Human volunteers have been studied to determine the interaction of remifentanil and ketamine on the perception of pain. Koppert and colleagues used a transdermal electrical stimulation module of forearm pain and compared remifentanil, ketamine, and clonidine to test analgesic or hyperalgesic properties of each alone or in combination. ${ }^{43}$ This group determined that the combination of remifentanil and ketamine prevented the development of opioid-induced hyperalgesia, but not secondary hyperalgesia, which was prevented by administration of clonidine. The hyperalgesic effect of remifentanil and ketamine was further studied by Angst and others in 10 normal adult male human volunteers. ${ }^{44}$ The investigators induced a hyperalgesic state in the skin of volunteers by intradermal electrical stimulation, and compared the men's perception of pain in both normal skin and in skin that was rendered hyperalgesic. The normal skin was exposed to thermal pain, which was induced by heating a circular thermode in contact with skin on the right forearm. The hyperalgesic skin was created on the left forearm and then exposed to mechanical pain, which consisted of applying a steel wire tip perpendicular to the skin. Hyperalgesia was believed to be present when men complained of the mechanical force causing pain in the area exposed to electrical stimulation, but not painful when the same force was applied to the opposite arm. The men were each tested four different times with either remifentanil or ketamine infusions alone, the two drugs combined, or placebo. Each patient was randomly selected for the order of each test and both the patient and observer were blinded to the specific drug combination on each test day. When comparing remifentanil and ketamine infusions alone, remifentanil was found to increase the area of hyperalgesic skin generated by the same electrical stimulation, but did not change perception of heat-related pain in the normal skin area. When a combination of remifentanil and ketamine were administered, there was no increase in area of hyperalgesic skin, providing further evidence for a possible role of NMDA antagonists in preventing opioid induced hyperalgesia. 
To study the interaction of remifentanil and ketamine in patients, Guignard and colleagues studied 50 patients undergoing colorectal surgery whose maintenance anesthetic consisted of desflurane and remifentanil, and were randomized to receive either placebo bolus saline followed by an infusion of saline, or a bolus of ketamine $0.15 \mathrm{mg} / \mathrm{kg}$ followed by a low dose ketamine infusion $2 \mu \mathrm{g} / \mathrm{kg} / \mathrm{min}{ }^{45}$ Patients in the ketamine group required less remifentanil intraoperatively to control autonomic responses. Postoperatively the ketamine group required morphine later and consumed significantly less morphine than the control group for the first 24 hours. In a study of patients undergoing abdominal surgery, Joly and colleagues reported the hyperalgesic effects of remifentanil and ketamine. In the patients who received intraoperative high dose remifentanil, larger areas of hyperalgesia surrounding the wound were noted, and these patients also required higher doses of postoperative morphine for pain control. Interestingly patients who received either low dose remifentanil alone, or large dose remifentanil and ketamine, showed similar areas of hyperalgesia and required similar doses of postoperative morphine. ${ }^{46}$

Other potential mediators of remifentanil induced hyperalgesia which have been studied include cyclooxygenase-2 inhibitor parecoxib and propofol. ${ }^{47,48}$ Administering parecoxib prior to the start of remifentanil infusion in healthy volunteers reduced the hyperalgesic response. ${ }^{48}$ There was no response if parecoxib was given simultaneously with remifentanil. Another study of healthy volunteers examined the effect of propofol infusion given simultaneously with remifentanil infusion. ${ }^{47}$ This study determined that a subhypnotic dose propofol infusion decreased, but did not completely eliminate, the hyperalgesia response seen after remifentanil infusion alone.

Morphine and ketamine have been studied to determine their role in hyperalgesia in pediatric patients receiving remifentanil as part of anesthetic management during scoliosis surgery. Crawford and others studied 30 pediatric scoliosis surgery patients randomly assigned to either continuous intraoperative infusion of remifentanil or bolus morphine doses. ${ }^{49}$ In the postoperative period, the patients were started on a morphine PCA, and after 24 hours the consumption of morphine was compared between the two groups. The group that had received remifentanil intraoperatively used $30 \%$ more morphine, suggesting that the intraoperative infusion was associated with the development of acute opioid tolerance. In an attempt to modify this tolerance, Engelhardt's group studied the role of low dose ketamine in pediatric scoliosis patients. ${ }^{50}$ During surgery remifentanil and propofol infusions were utilized for maintenance anesthesia for all patients. Patients were then randomized to receive either bolus ketamine $(0.5 \mathrm{mg} / \mathrm{kg})$ followed by low dose infusion $(4 \mu \mathrm{g} / \mathrm{kg} / \mathrm{min})$ or saline placebo. Patients were studied for the next 72 hours with respect to pain scores, morphine consumption, and sedation scores. There was no distinguishable difference in postoperative pain scores or morphine consumption between the two groups, suggesting that low dose ketamine does not effect the development of acute opioid tolerance in these patients. McDonnell's group also examined pediatric scoliosis patients utilizing remifentanil intraoperatively. ${ }^{51}$ This group randomized 40 patients to receive either $150 \mu \mathrm{g} / \mathrm{kg}$ of morphine or placebo prior to remifentanil infusion. The investigators noted no difference in 24-hour morphine consumption, pain scores, sedation levels, or incidence of nausea or vomiting. Thus, pre-treatment with morphine does not appear to modify remifentanil-induced hyperalgesia.

\section{Summary}

Remifentanil's unique pharmacokinetic profile confers the drug with rapid onset and offset of action. The drug's flat context-sensitive half-time makes it clinically predictable with respect to pharmacodynamic properties. An ultrashort half-life makes remifentanil a drug that can be used for patients with a wide variety of clinical disorders and in a wide age range of patients. Use of remifentanil during general anesthesia can result in rapid recovery times, but this has not resulted in faster facility discharge times and may in fact result in increased postoperative pain. Combination of remifentanil with regional anesthesia results in excellent sedation but increased hypoxia, respiratory depression, and nausea. Pain relief after surgery can be well controlled with remifentanil PCA, but respiratory depression is a serious side effect that mandates close observation. Labor analgesia may also be effectively provided by remifentanil PCA, however, there are limited studies comparing PCA with neuraxial analgesia. Because remifentanil is so short acting, concerns regarding its ability to induce tolerance and hyperalgesia in patients have been raised, but not definitively answered. NMDA antagonist, ketamine, cycoloxygenase-2 inhibitor parecoxib, and propofol have been studied to determine the effect on remifentanil induced hyperalgesia. The results are inconclusive and study populations small, highlighting the need for additional study to combat this phenomena. 


\section{Disclosure}

The authors declare no conflicts of interest.

\section{References}

1. Glass PS, Hardman D, Kamiyama Y, et al. Preliminary pharmacokinetics and pharmacodynamics of an ultra-short-acting opioid: remifentanil (GI87084B). Anesth Analg. 1993;77:1031-1040.

2. Jablonka DH, Davis PJ. Opioids in pediatric anesthesia. Anesthesiol Clin North America. 2005;23:621-634, viii

3. Ross AK, Davis PJ, Dear Gd GL, et al. Pharmacokinetics of remifentanil in anesthetized pediatric patients undergoing elective surgery or diagnostic procedures. Anesth Analg. 2001;93:1393-1401.

4. Egan TD, Lemmens HJ, Fiset P, et al. The pharmacokinetics of the new short-acting opioid remifentanil (GI87084B) in healthy adult male volunteers. Anesthesiology. 1993;79:881-892.

5. Kapila A, Glass PS, Jacobs JR, et al. Measured context-sensitive half-times of remifentanil and alfentanil. Anesthesiology. 1995;83:968-975.

6. Navapurkar VU, Archer S, Gupta SK, et al. Metabolism of remifentanil during liver transplantation. Br J Anaesth. 1998;81:881-886.

7. Hoke JF, Shlugman D, Dershwitz M, et al. Pharmacokinetics and pharmacodynamics of remifentanil in persons with renal failure compared with healthy volunteers. Anesthesiology. 1997;87:533-541.

8. Davis PJ, Stiller RL, Wilson AS, et al. In vitro remifentanil metabolism: the effects of whole blood constituents and plasma butyrylcholinesterase. Anesth Analg. 2002;95:1305-1307, table of contents.

9. Manullang J, Egan TD. Remifentanil's effect is not prolonged in a patient with pseudocholinesterase deficiency. Anesth Analg. 1999;89:529-530.

10. Lang E, Kapila A, Shlugman D, et al. Reduction of isoflurane minimal alveolar concentration by remifentanil. Anesthesiology. 1996;85:721-728.

11. Song D, White PF. Remifentanil as an adjuvant during desflurane anesthesia facilitates early recovery after ambulatory surgery. J Clin Anesth. 1999;11:364-367.

12. Beers RA, Calimlim JR, Uddoh E, Esposito BF, Camporesi EM. A comparison of the cost-effectiveness of remifentanil versus fentanyl as an adjuvant to general anesthesia for outpatient gynecologic surgery. Anesth Analg. 2000;91:1420-1425.

13. Hong JY, Kang YS, Kil HK. Anaesthesia for day case excisional breast biopsy: propofol-remifentanil compared with sevoflurane-nitrous oxide. Eur J Anaesthesiol. 2008;25:460-467.

14. Larsen B, Seitz A, Larsen R. Recovery of cognitive function after remifentanil-propofol anesthesia: a comparison with desflurane and sevoflurane anesthesia. Anesth Analg. 2000;90:168-174.

15. Davis PJ, Finkel JC, Orr RJ, et al. A randomized, double-blinded study of remifentanil versus fentanyl for tonsillectomy and adenoidectomy surgery in pediatric ambulatory surgical patients. Anesth Analg. 2000;90:863-871.

16. Eltzschig HK, Schroeder TH, Eissler BJ, et al. The effect of remifentanil or fentanyl on postoperative vomiting and pain in children undergoing strabismus surgery. Anesth Analg. 2002;94:1173-1177.

17. Davis PJ, Lerman J, Suresh S, et al. A randomized multicenter study of remifentanil compared with alfentanil, isoflurane, or propofol in anesthetized pediatric patients undergoing elective strabismus surgery. Anesth Analg. 1997;84:982-989.

18. Hayes JA, Lopez AV, Pehora CM, et al. Coadministration of propofol and remifentanil for lumbar puncture in children: dose-response and an evaluation of two dose combinations. Anesthesiology. 2008;109:613-618.

19. Lauwers M, Camu F, Breivik H, et al. The safety and effectiveness of remifentanil as an adjunct sedative for regional anesthesia. Anesth Analg. 1999;88:134-140.

20. Lauwers MH, Vanlersberghe $\mathrm{C}$, Camu F. Comparison of remifentanil and propofol infusions for sedation during regional anesthesia. Reg Anesth Pain Med. 1998;23:64-70.
21. Mingus ML, Monk TG, Gold MI, Jenkins W, Roland C. Remifentanil versus propofol as adjuncts to regional anesthesia. Remifentanil 3010 Study Group. J Clin Anesth. 1998;10:46-53.

22. Servin FS, Raeder JC, Merle JC, et al. Remifentanil sedation compared with propofol during regional anaesthesia. Acta Anaesthesiol Scand. 2002;46:309-315.

23. Krenn H, Deusch E, Jellinek H, Oczenski W, Fitzgerald RD. Remifentanil or propofol for sedation during carotid endarterectomy under cervical plexus block. Br J Anaesth. 2002;89:637-640.

24. Savoia G, Loreto M, Gravino E, et al. Monitored anesthesia care and loco-regional anesthesia. Vascular surgery use. Minerva Anestesiol. 2005;71:539-542.

25. Hohener D, Blumenthal S, Borgeat A. Sedation and regional anaesthesia in the adult patient. BrJ Anaesth. 2008;100:8-16.

26. Mandel JE, Tanner JW, Lichtenstein GR, et al. A randomized, controlled, double-blind trial of patient-controlled sedation with propofol/ remifentanil versus midazolam/fentanyl for colonoscopy. Anesth Analg. 2008;106:434-439, table of contents.

27. Moerman AT, Herregods LL, De Vos MM, Mortier EP, Struys MM. Manual versus target-controlled infusion remifentanil administration in spontaneously breathing patients. Anesth Analg. 2009; 108:828-834.

28. Choi SH, Koo BN, Nam SH, et al. Comparison of remifentanil and fentanyl for postoperative pain control after abdominal hysterectomy. Yonsei Med J. 2008;49:204-210.

29. Koo BN, Choi SH, Chun DH, et al. Respiratory depression caused by remifentanil infusion for postoperative pain control. Anesth Analg. 2006;103:1627-1628.

30. Kucukemre F, Kunt N, Kaygusuz K, et al. Remifentanil compared with morphine for postoperative patient-controlled analgesia after major abdominal surgery: a randomized controlled trial. Eur J Anaesthesiol. 2005;22:378-385

31. Gurbet A, Goren S, Sahin S, Uckunkaya N, Korfali G. Comparison of analgesic effects of morphine, fentanyl, and remifentanil with intravenous patient-controlled analgesia after cardiac surgery. J Cardiothorac Vasc Anesth. 2004;18:755-758.

32. Baltali S, Turkoz A, Bozdogan N, et al. The efficacy of intravenous patient-controlled remifentanil versus morphine anesthesia after coronary artery surgery. J Cardiothorac Vasc Anesth. 2009;23:170-174.

33. Hinova A, Fernando R. Systemic remifentanil for labor analgesia. Anesth Analg. 2009;109:1925-1929.

34. Volmanen P, Akural EI, Raudaskoski T, Alahuhta S. Remifentanil in obstetric analgesia: a dose-finding study. Anesth Analg. 2002;94: 913-917, table of contents.

35. Volmanen P, Sarvela J, Akural EI, et al. Intravenous remifentanil vs epidural levobupivacaine with fentanyl for pain relief in early labour: a randomised, controlled, double-blinded study. Acta Anaesthesiol Scand. 2008:52:249-255.

36. Blair JM, Hill DA, Fee JP. Patient-controlled analgesia for labour using remifentanil: a feasibility study. Br J Anaesth. 2001;87:415-420.

37. Angst MS, Clark JD. Opioid-induced hyperalgesia: a qualitative systematic review. Anesthesiology. 2006;104:570-587.

38. Schmidt S, Bethge C, Forster MH, Schafer M. Enhanced postoperative sensitivity to painful pressure stimulation after intraoperative high dose remifentanil in patients without significant surgical site pain. Clin $J$ Pain. 2007;23:605-611.

39. Cabanero D, Campillo A, Celerier E, Romero A, Puig MM. Pronociceptive effects of remifentanil in a mouse model of postsurgical pain: effect of a second surgery. Anesthesiology. 2009;111:1334-1345.

40. Zhao M, Joo DT. Enhancement of spinal N-methyl-D-aspartate receptor function by remifentanil action at delta-opioid receptors as a mechanism for acute opioid-induced hyperalgesia or tolerance. Anesthesiology. 2008;109:308-317.

41. Fu ES, Miguel R, Scharf JE. Preemptive ketamine decreases postoperative narcotic requirements in patients undergoing abdominal surgery. Anesth Analg. 1997;84:1086-1090. 
42. Guillou N, Tanguy M, Seguin P, et al. The effects of small-dose ketamine on morphine consumption in surgical intensive care unit patients after major abdominal surgery. Anesth Analg. 2003;97:843-847.

43. Koppert W, Sittl R, Scheuber K, et al. Differential modulation of remifentanil-induced analgesia and postinfusion hyperalgesia by S-ketamine and clonidine in humans. Anesthesiology. 2003;99:152-159.

44. Angst MS, Koppert W, Pahl I, Clark DJ, Schmelz M. Short-term infusion of the mu-opioid agonist remifentanil in humans causes hyperalgesia during withdrawal. Pain. 2003;106:49-57.

45. Guignard B, Coste C, Costes H, et al. Supplementing desfluraneremifentanil anesthesia with small-dose ketamine reduces perioperative opioid analgesic requirements. Anesth Analg. 2002;95:103-108, table of contents.

46. Joly V, Richebe P, Guignard B, et al. Remifentanil-induced postoperative hyperalgesia and its prevention with small-dose ketamine. Anesthesiology. 2005;103:147-155.

47. Singler B, Troster A, Manering N, Schuttler J, Koppert W. Modulation of remifentanil-induced postinfusion hyperalgesia by propofol. Anesth Analg. 2007;104:1397-1403, table of contents.
48. Troster A, Sittl R, Singler B, et al. Modulation of remifentanil-induced analgesia and postinfusion hyperalgesia by parecoxib in humans. Anesthesiology. 2006;105:1016-1023.

49. Crawford MW, Hickey C, Zaarour C, Howard A, Naser B. Development of acute opioid tolerance during infusion of remifentanil for pediatric scoliosis surgery. Anesth Analg. 2006;102:1662-1667.

50. Engelhardt T, Zaarour C, Naser B, et al. Intraoperative low-dose ketamine does not prevent a remifentanil-induced increase in morphine requirement after pediatric scoliosis surgery. Anesth Analg. 2008;107:1170-1175.

51. McDonnell C, Zaarour C, Hull R, et al. Pre-treatment with morphine does not prevent the development of remifentanil-induced hyperalgesia. Can J Anaesth. 2008;55:813-818.
Local and Regional Anesthesia

\section{Publish your work in this journal}

Local and Regional Anesthesia is an international, peer-reviewed, open access journal publishing on the development, pharmacology, delivery and targeting and clinical use of local and regional anesthetics and analgesics. The journal welcomes submitted papers covering original research, basic science, clinical studies, reviews \& evaluations,

\section{Dovepress}

guidelines, expert opinion and commentary, case reports and extended reports. The manuscript management system is completely online and includes a very quick and fair peer-review system, which is all easy to use. Visit http://www.dovepress.com/testimonials.php to read real quotes from published authors.

Submit your manuscript here: http://www.dovepress.com/local-and-regional-anesthesia-journal 